\title{
Recognition and Treatment of Severe COVID-19 in Pregnancy: Lessons from a Cohort of 69 Infected Women and an Evidence-Based Guideline
}

Rebecca Scott ${ }^{1}$, Hilary Hewitt ${ }^{1}$, Camille Mallet ${ }^{1}$, Leone Herd $^{2}$, Carole Shibley ${ }^{3}$, Sally Bolger $^{2}$, Islean Kinghorn ${ }^{4}$, Sarah-Kate Mcleavey ${ }^{4}$, Adewale Adeyemo ${ }^{3}$, Alison Wright ${ }^{2}$, Amma Kyei-Mensah ${ }^{5}$, Melissa Whitten ${ }^{1}$, Eleni Nastouli ${ }^{1}$, Mervyn Singer ${ }^{1}$, and David Williams ${ }^{6}$

${ }^{1}$ University College London Hospitals NHS Foundation Trust

${ }^{2}$ Royal Free London NHS Foundation Trust

${ }^{3}$ North Middlesex University Hospital NHS Trust

${ }^{4}$ Whittington Health NHS Trust

${ }^{5}$ Whittington Hospital NHS Trust

${ }^{6}$ University College London Institute for Women's Health

November 23, 2020

\begin{abstract}
Objectives: To determine clinical and laboratory features of pregnant woman with COVID-19 who require respiratory support. To recommend a management strategy that optimises maternal and fetal outcomes. Design: An observational cohort study of 7000 maternities between 1st March and 1st July 2020. Setting: Five maternity centres across a maternal medicine network in north-central London, UK Population: 69 pregnant women with confirmed acute SARS-COV2 Methods: Review of electronic healthcare records Main Outcome Measures: Clinical and laboratory features, maternal and fetal outcomes. Results: Respiratory support was needed by $15 / 69$. This cohort was more likely to present with dyspnoea $(10 / 15$ vs $10 / 54, \mathrm{p}<0.001)$, a lower lymphocyte count (0.9?0.1 vs $1.4 ? 0.1 \times 109$ cells/L; p<0.01) and hypokalaemia (3.8?0.1 vs 4.0?0.1 mmol/l, p<0.05). Radiological evidence of lung consolidation did not identify women in need of respiratory support. Women on respiratory support underwent childbirth at an earlier gestation than those who did not $(36+4$ vs $39+5$ weeks, $\mathrm{p}<0.001)$, and required emergency c-section $(6 / 15$ vs $8 / 54, \mathrm{p}<0.05)$. Childbirth did not improve respiratory function in those with severe disease, with 3 women remaining on invasive ventilation despite childbirth. Conclusions: Routine clinical data can identify pregnant women at risk of severe COVID-19. Pregnant women should be offered the same treatment as non-pregnant patients but iatrogenic childbirth should not be the default for women with severe disease. We propose a management pathway for pregnant women with severe COVID-19.
\end{abstract}

\section{Hosted file}

221120 Recognition and Treatment of Severe COVID in pregnancy [1] [2].pdf available at https://authorea.com/users/378177/articles/494724-recognition-and-treatment-of-severecovid-19-in-pregnancy-lessons-from-a-cohort-of-69-infected-women-and-an-evidence-basedguideline

\section{Hosted file}

201118table1.pdf available at https://authorea.com/users/378177/articles/494724-recognition- 
and-treatment-of-severe-covid-19-in-pregnancy-lessons-from-a-cohort-of-69-infectedwomen-and-an-evidence-based-guideline

\section{Hosted file}

201118table2.pdf available at https://authorea.com/users/378177/articles/494724-recognitionand-treatment-of-severe-covid-19-in-pregnancy-lessons-from-a-cohort-of-69-infectedwomen-and-an-evidence-based-guideline

\section{Hosted file}

201118table3.pdf available at https://authorea.com/users/378177/articles/494724-recognitionand-treatment-of-severe-covid-19-in-pregnancy-lessons-from-a-cohort-of-69-infectedwomen-and-an-evidence-based-guideline

\section{Hosted file}

201118table4.pdf available at https://authorea.com/users/378177/articles/494724-recognitionand-treatment-of-severe-covid-19-in-pregnancy-lessons-from-a-cohort-of-69-infectedwomen-and-an-evidence-based-guideline

\section{Hosted file}

201118table5.pdf available at https://authorea.com/users/378177/articles/494724-recognitionand-treatment-of-severe-covid-19-in-pregnancy-lessons-from-a-cohort-of-69-infectedwomen-and-an-evidence-based-guideline

\section{Hosted file}

201118fig1.pdf available at https://authorea.com/users/378177/articles/494724-recognitionand-treatment-of-severe-covid-19-in-pregnancy-lessons-from-a-cohort-of-69-infectedwomen-and-an-evidence-based-guideline

\section{Hosted file}

201122fig2.pdf available at https://authorea.com/users/378177/articles/494724-recognitionand-treatment-of-severe-covid-19-in-pregnancy-lessons-from-a-cohort-of-69-infectedwomen-and-an-evidence-based-guideline

\section{Hosted file}

201118figure3.pdf available at https : //authorea.com/users/378177/articles/494724-recognitionand-treatment-of-severe-covid-19-in-pregnancy-lessons-from-a-cohort-of-69-infectedwomen-and-an-evidence-based-guideline 